\title{
Efficient Protocol for Mini-tuber Production in Potato (Solanum tuberosum L.) Cultivar Kufri Frysona
}

\author{
Priyadarshani P. Mohapatra ${ }^{1,2^{*}}$, Mounika Poonia ${ }^{2}$, V.K. Batra ${ }^{1}$, S. Kajla ${ }^{2}$ and A. Poonia ${ }^{2}$ \\ ${ }^{1}$ Department of Vegetable Science, CCS HAU, Hisar-125001, Haryana, India \\ ${ }^{2}$ Centre for Plant Biotechnology, CCS HAU Campus, Hisar-125004, India \\ *Corresponding author
}

\begin{tabular}{|c|c|}
\hline & A B S T R A C T \\
\hline Keywords & \multirow{4}{*}{$\begin{array}{l}\text { The present investigation was conducted in Centre for Plant } \\
\text { Biotechnology lab and Vegetable Science Farm, CCSHAU, Hisar in the } \\
\text { year 2013-14 to develop the efficient protocol for mini-tuber production in } \\
\text { potato cultivar Kufri frysona. The total numbers of mini-tubers were } 3 \text { to } 5 \\
\text { times higher from each in vitro plantlet that was sectioned into nodal } \\
\text { cuttings. The protocol will be very useful for large-scale production of } \\
\text { potato in future. }\end{array}$} \\
\hline $\begin{array}{l}\text { Mini-Tuber, } \\
\text { Potato, In vitro } \\
\text { and Nodal } \\
\text { cuttings. }\end{array}$ & \\
\hline Article Info & \\
\hline $\begin{array}{l}\text { Accepted: } \\
\text { 06 March } 2017 \\
\text { Available Online: } \\
10 \text { April } 2017\end{array}$ & \\
\hline & \\
\hline
\end{tabular}

\section{Introduction}

Potato is one of the world's most economically important tuber crops and belonging to the family Solanaceae. India is the second largest producer of potato in the world after China, and the crop occupies 2.134 million hectares with a total production of 43.77 million tones estimated data (Anonymous, 2015-16). And also produces more edible energy and protein per unit area and time than many other crops. It is a staple food in many countries. Most potato growers in developing countries do not use quality seed, because of high costs and lack of access. As a result, there is a high need for cost-effective methods to produce quality seed that can be accessed by small farmers at affordable cost. Through Micro-propagation allows quick and round-the-year production of disease-free good quality seed and thus is a way out to supplement the ever increased demand of quality seed as mini-tuber. Minitubers were first described in potato, but as a seed propagule is not adapted much. However, the application of minitubers in germplasm conservation is widely accepted. Accordingly, minitubers come in different sizes, have different dormancy requirements, and differ widely in relative growth potential and productivity. The use of minituber technology in seed tuber production, 
breeding programs, germplasm conservation, and research appears to have enormous potential.

The main objectives of this study to develop efficient technique for Mini-tuber production in potato cv. Kufri Frysona.

\section{Materials and Methods}

Production protocol of potato mini-tubers, cv Kufri Frysona, has been carried out in Centre for Plant Biotechnology lab and Vegetable Science Farm. According to protocols based on in vitro methods. Sprouts and Shoot tips were used as explants. Sterilization of explants were done using bavistin $(0.2 \%)$ and streptocycline $(0.4 \%)$ for 45 minutes followed by treatment with $\mathrm{HgCl}_{2}(0.1 \%)$ for 60 seconds. Sterilized explants were inoculated on MS basal supplemented with various growth regulators and established successfully. The sprouted explants were further sub-cultured on MS media supplemented with various growth regulator alone and in combination for in vitro multiplication. Self rooted microplants were successfully hardened in green house using different types of potting mixture and finally transferred to field to produced mini-tuber in field.

\section{Results and Discussion}

The number of mini-tubers produced/plant was 9-10 for cv. Kufri Frysona and maximum average weight was $11.5 \pm 3.77 \mathrm{~g}$. The largest diameter of minitubers was $2.9 \pm 0.43 \mathrm{~cm}$. Minituber behavior under field conditions was independent from the technique used for its production. Grigoriadou and Leventakis (1999) developed large scale, commercial production of potato minitubers, cvs Spunta, Jaerla and Kennebec, has been carried out in vitro, according to protocols based on in vitro methods. Apical meristems were cultured on
MS medium supplemented with $1 \mu \mathrm{M}$ IBA, $20 \mathrm{~g} / \mathrm{l}$ sucrose and $6 \mathrm{~g} / \mathrm{l}$ agar $(\mathrm{pH}$ 5.8). Subculture was carried out every 15 days. Multiplication rate was 4-5 per cycle. Selfrooted microplants were transferred into screen houses $\left(200\right.$ plants $\left./ \mathrm{m}^{2}\right)$ in a mixture of peat and perlite 1:1 (v/v). Cultivation period was 15 August to 15 November each year. During the period 1995-1997, the number of minitubers produced/plant was 2.07 for $\mathrm{cv}$. Spunta, 1.85 for cv. Jaerla and 2.52 for cv. Kennebec and their average weights were $10.8 \mathrm{~g}, 10.9 \mathrm{~g}$ and $9.8 \mathrm{~g}$, respectively. The percentage of minitubers $<10 \mathrm{~mm}$ in diameter was $2 \%, 50.1 \%$ were $10-20 \mathrm{~mm}$ and $47.9 \%$ were $>20 \mathrm{~mm}$. Hypocotyl of in vitro germinated seedlings was taken as explants. Ghosh and Chatterjee (2009) Hypocotyl explants were cultured in both Murashige and Skoog's (1962) (MS) and Schenk and Hildebrand's (1972) (SH) basal media supplemented with different growth regulators in definite concentrations. Callus growth was found better in MS basal medium than SH medium.

For morphogenetic study the hypocotyl callus tissues were grown in medium containing different combinations and concentrations of auxins (IAA, NAA, IBA and 2,4-D used separately @ $0.20 \mathrm{mg} / \mathrm{L}$ ) and cytokinins (BAP and Kinetin used separately $0.15 \mathrm{mg} / \mathrm{K}$ to $3.2 \mathrm{mg} / \mathrm{L}$, coconut milk $10-35 \%$ volume/volume). A simplified method for morphogenesis of calli was standardized. Cytological studies of the regenerated roots from calli as well as from regenerated plants revealed diploid chromosome number while the calli were mixoploid in nature. It was observed that the balance in the concentration of auxin-cytokinin (in initial culture) as well as ploidy level in the cells is most importantfactors in controlling differentiation.

Willemien and Lommen (1994) studied behaviour of minitubers in five weight 
classes, having mid-point values between 0.19 and $3.00 \mathrm{~g}$, during sprouting and emergence under controlled conditions. Lighter tubers took longer to produce sprouts of $2 \mathrm{~mm}$, and their sprouts grew more slowly between 2 and $4 \mathrm{~mm}$ and 4 and $6 \mathrm{~mm}$. As sprouts lengthened their rate of growth increased (Table 1). The influence of tuber weight was less for heavier tubers and also decreased as the sprouts grew longer. When tubers with sprouts of the same length were planted in pots, sprouts from lighter tubers took longer to emerge.

Table.1 Average size and weight of minitubers from the field

\begin{tabular}{|c|c|c|}
\hline \multirow{2}{*}{ Sr. No. } & \multicolumn{2}{|c|}{ Kufri Frysona } \\
\cline { 2 - 3 } & Minituber size area (cm.) & Weight $\mathbf{( g )}$ \\
\hline 1 & $1.3 \pm 0.27$ & $1.7 \pm 0.94$ \\
\hline 2 & $2.2 \pm 0.30$ & $6.2 \pm 2.08$ \\
\hline 3 & $1.4 \pm 0.32$ & $2.1 \pm 0.92$ \\
\hline 4 & $1.3 \pm 0.20$ & $2.0 \pm 0.65$ \\
\hline 5 & $2.9 \pm 0.43$ & $11.5 \pm 3.77$ \\
\hline 6 & $0.9 \pm 0.28$ & $1.2 \pm 0.47$ \\
\hline 7 & $0.8 \pm 0.19$ & $1.08 \pm 0.36$ \\
\hline 8 & $0.6 \pm 0.20$ & $0.51 \pm 0.26$ \\
\hline 9 & $0.9 \pm 0.23$ & $0.43 \pm 0.20$ \\
\hline SE(m) & 0.28 & 1.536 \\
\hline CD at 5\% & 0.84 & 4.60 \\
\hline
\end{tabular}

Fig.1 Tissue culture raised plants in the field
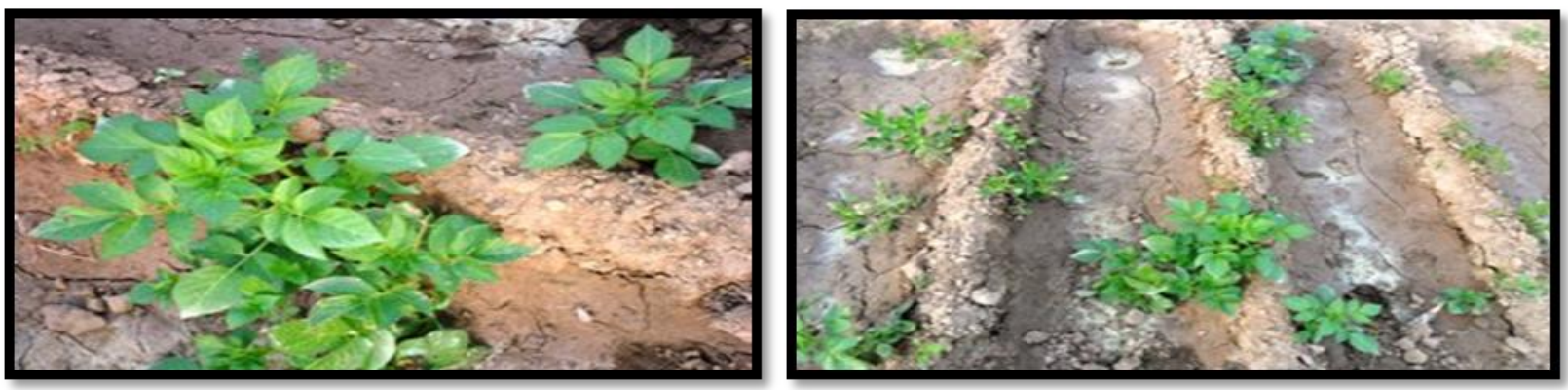

Fig.2 Minitubers from field

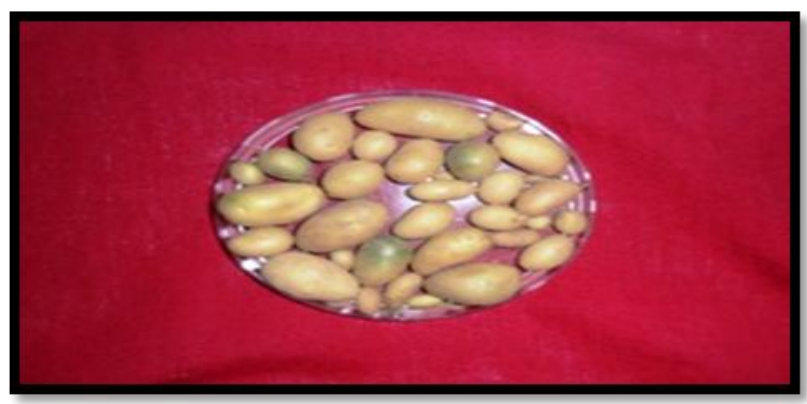


Emergence was later and differences between weight classes were larger when tubers were planted deeper $(6$ or $9 \mathrm{~cm})$ or when they had shorter sprouts at planting ( 2 or $4 \mathrm{~mm}$ ). At emergence, plants from lighter tubers had thinner stems and lower stem and root weights, but higher stem weights proportional to tuber weights and higher shoot: root ratios (Figs 1 and 2).

In another research Ali et al., (1995) supported that in vitro culture nodal plant produced more minitubers. The terminal Node-5 cutting and WIP produced significantly larger minitubers $>3.0 \mathrm{~g}$ as compared to single node cuttings. Greater numbers of minitubers were produced by the cvs Norchip, Red Pontiac and Conestoga as compared to cvs Eramosa. G8610-4PY and Shepody. Total numbers of minitubers were 3 to 5 times higher from each in vitro plantlet that was sectioned into nodal cuttings as compared with intact WIP: the yield ratios depended on cultivar.

In conclusion, total numbers of minitubers were 3 to 5 times higher from each in vitro plantlet that was sectioned into nodal cuttings. So getting disease-free good quality seed and thus in vitro is a way out to supplement the ever increased demand of quality seed.

\section{References}

Ahmed Ali, S.M.M., Alam, V., Souza Machado. 1995. Potato minituber production from nodal cuttings compared to wholein vitro plantlets using low volume media in a greenhouse, Potato Res., Vol 38: 1, pp 69-76.

Anonymous. 2015-16. National Horticulture Database, National Horticulture Board, Ministry of Agriculture, Govt. of India.

Ghosh, P.K., and A. Chatterjee. 2009. Regeneration of plants from hypocotyl derived callus tissue of jute (Corchorus olitorius L. var. JRO-632) J. Crop and Weed, Vol.5: 2 pp19.

Grigoriadou, K., N. Leventakis. 1999. Large scale commercial production of potato minitubers, using in vitro techniques, Potato Res., Vol 42: 3, pp 607-610.

Murashige, T., and F. Skoog. 1962. A revised medium for rapid growth and bioassays with tobacco cultures. J. Plant Physiol., 15: 473-479.

Willemien, J.M., Lommen. 1994. Effect of weight of potato minitubers on sprout growth, emergence and plant characteristics at emergence, Potato Res., Vol 37: 3, pp 315-322.

\section{How to cite this article:}

Priyadarshani P. Mohapatra, Mounika Poonia, V.K. Batra, S. Kajla and A. Poonia. 2017. Efficient Protocol for Mini-tuber Production in Potato (Solanum tuberosum L.) Cultivar Kufri Frysona. Int.J.Curr.Microbiol.App.Sci. 6(4): 889-892.

doi: https://doi.org/10.20546/ijcmas.2017.604.112 